\title{
Radiation-induced senescence and thyroid cancer: a barrier or a driving force
}

\section{Senescência e câncer de tiróide induzido por radiação: uma barreira ou uma força motriz}

\author{
Ricardo Cortez Cardoso Penhaa, Sheila Coelho Soares Limab, \\ Luis Felipe Ribeiro Pintoc, Alfredo Fuscod \\ - Instituto Nacional de Câncer - INCA, Rio de Janeiro, RJ, Brazil. <ricardocortezcardoso@gmail.com> \\ b Instituto Nacional de Câncer - INCA, Rio de Janeiro, RJ, Brazil. < sheilacoelho@gmail.com>. \\ Instituto Nacional de Câncer - INCA, Rio de Janeiro, RJ, Brazil.<lfrpinto@inca.gov.br>. \\ d Instituto Nacional de Câncer - INCA, Rio de Janeiro, RJ, Brazil. Istituto di Endocrinologia ed Oncologia Sperimentale del CNR c/o Dipartimento \\ di Medicina Molecolare e Biotecnologie Mediche, Università degli Studi di Napoli "Federico II", Napoli, Italy. <alfusco@unina.it>.
}

\section{ARTICLE INFO}

\section{Article history}

Received: 24/06/2015

Accepted: 12/10/2015

\section{Correspondent Author}

Alfredo Fusco

Istituto di Endocrinologia e Oncologia Sperimentale del CNR

Dipartimento di Medicina Molecolare e Biotecnologie Mediche

Universita degli Studi di Napoli "Federico II"

Via Sergio Pansini, 5

80131 Napoli, Italy

<alfusco@unina.it>

\section{(C) 2015 All rights reserved}

\section{Editors}

Alfredo Cataldo Neto

Irenio Gomes

\begin{abstract}
Aims: The main goal of this review-article was to shed light on the impact of senescence on thyroid carcinogenesis, a promising but still neglected field. Source of data: PubMed database and Google Scholar search was performed for English language articles with terms: ionizing radiation exposure, thyroid cancer, radiation signature, RET/PTC, senescence and radiation-induced senescence. We have no date restrictions. Summary of findings: lonizing radiation (IR) is undoubtedly the most well-characterized risk factor for thyroid cancer of the papillary histotype and its pivotal role as senescence inducer has been proposed. A paradoxical role of senescence on carcinogenesis - a barrier to cancer cell proliferation in early steps and a driving force to cancer progression by secreting proinflamatory cytokines and matrix degrading enzymes - is the heart of the matter of age-related cancer and bring to life new insights to thyroid cancer research field. This review-article briefly points out the major findings that link ionizing radiation to thyroid carcinogenesis, highlighting the molecular alterations mediated by acute and chronic radiation exposure in thyroid cells. Conclusions: Evidences provided by our group and other few reports suggest that, like other oncogenic stimuli in different cell types, IR induces a senescent phenotype in thyroid cells, what could represent an initial barrier to transformation. However, how senescence could contribute to tumor progression still remains elusive. The comprehension of these mechanisms could not only help elucidating thyroid cancer initiation and progression, but could also indicate new therapeutical targets. KEYWORDS: lonizing radiation; Thyroid cancer; Senescence; DNA damage; RET/PTC.
\end{abstract}

\begin{abstract}
RESUMO
Objetivos: $\bigcirc$ principal objetivo deste artigo de revisão foi lançar luz sobre o impacto da senescência na carcinogênese da tiroide, um campo promissor, mas ainda negligenciado. Fonte dos dados: pesquisa nos bancos de dados PubMed e Google Scholar realizada para artigos em inglês com os termos: exposição à radiação ionizante, câncer de tireoide, radiação assinatura, RET/PTC, senescência e senescência induzida por radiação. Não houve restrições quanto a data. Resumo das constatações: radiação ionizante (IR) é, sem dúvida, o fator de risco mais bem caracterizado para o câncer de tireoide de histotipo papilar e seu papel central como indutor de senescência tem sido proposto. Um papel paradoxal da senescência na carcinogênese - uma barreira a proliferação celular cancerígena em etapas precoces e uma força motriz para a progressão do câncer através de secreção de citocinas pró-inflamatórias e enzimas matriz degradantes - é o foco principal sobre o câncer relacionado à idade e trazem à vida novos insights para a investigação do câncer de tiroide. Este artigo de revisão mostra brevemente as principais conclusões que apontam a radiação ionizante à carcinogênese de tireoide, destacando as alterações moleculares mediadas pela exposição aguda e crônica à radiação em células da tireoide. Conclusões: Evidências fornecidas por nosso grupo e outros poucos relatos sugerem que, tal como outros estímulos oncogênicos em diferentes tipos de células, IR induz um fenótipo senescente em células da tireoide, o que poderia representar uma barreira inicial a transformação. No entanto, como a senescência poderia contribuir para a progressão do tumor ainda permanece indefinida. A compreensão destes mecanismos não só poderia ajudar a elucidar a iniciação e progressão do câncer de tireoide, mas também pode indicar novos alvos terapêuticos.
\end{abstract}

DESCRITORES: Radiação ionizante; Câncer de tireoide; Senescência; Danos no ADN; RET/PTC. 
THYROID CANCER AND IONIZING RADIATION

Thyroid cancer is one of the most common endocrine-related neoplasia. 1 Its incidence rates have been continuously growing among developed countries, and also in developing countries, which includes Brazil, where 9,200 new cases are estimated in $2014,{ }^{2}$ mainly due to the increase in papillary thyroid carcinoma (PTC) (Cramer et al. 2010) and the availability of diagnostic tools. The vast majority of differentiated thyroid carcinomas are PTC (80\%), ${ }^{3}$ that in almost all the cases retain the ability to uptake iodine and express differentiation markers, as thyroglobulin, essentials for thyroid normal function. ${ }^{4}$ Therefore, most PTC are highly curable and have good prognosis with an overall 5-year relative survival rate of about $90 \% .^{5}$

Ionizing radiation (IR) is a well-established risk factor for thyroid cancer. ${ }^{5}$ This finding was reinforced by Ron et al. $(1995)^{6}$ that performed a pooled analysis based on several reports and observed an increase in thyroid tumor rates, mostly PTC, in populations exposed to IR - atomic bomb survivors in Japan (1945) and patients irradiated during childhood for tonsil, tinea capitis, and cancer - and found a 7.7 excess relative risk per Gy (ERR/Gy) through linear dose-response models, previously applied to a japanese A-bomb survivors life span study. In addition to that, nuclear test detonations in Marshall islands (1946-1958) significantly contributed to higher thyroid cancer rates in populations living around the archipelago (cumulative 0.1-10 Gy thyroid mean radiation dose). ${ }^{7}$ Above all, these data highlighted that thyroid is more susceptible to the carcinogenic action of IR during childhood, especially in infants up to 5 years old, observed after Chernobyl accident (1987). ${ }^{8,9}$ Currently, the main sources of radiation exposure are medical procedures $(20 \%, 0.62 \mathrm{mSv})$ and environmental $(80 \%, 2.4 \mathrm{mSv}) .{ }^{10}$

\section{MOLECULAR MECHANISMS UNDERLYING RADIATION-RELATED THYROID CARCINOMAS}

Radiation-related carcinogenesis could be attributed to DNA base damages (3,000/Gy), DNA single strand breaks $(1,000 / \mathrm{Gy})$ and to a larger extent, DNA double strand breaks (DSB) $(40 / G y),{ }^{11,12}$ that might lead to mutations, deletions and chromosomal rearrangements. ${ }^{13}$ DSB formation is particularly associated to chromosomal rearrangements involved in PTC induction. ${ }^{4,14}$
Sporadic or radiation-related PTC have distinct molecular etiology and radiation seems to confer a specific gene expression signature to thyroid carcinomas. ${ }^{15}$ Post-Chernobyl childhood PTC have higher frequency of RET/PTC1 and RET/ PTC3 (50-90\%) than PTC cases with no radiationexposure background (13-43\%). 4,16,17 In fact, gammaradiation exposure can induce RET rearrangements in a dose-dependent manner in human thyroid cells. ${ }^{14}$ RET/PTC, which is a fusion product of RET tyrosine kinase domain sequence with heterologous genes, was originally demonstrated in PTC DNA extracted samples, with transforming activity. ${ }^{18}$ Sporadic PTC harbor BRAF $_{\text {V600E }}$ mutation $(46 \% \text { vs. } 12 \%)^{19}$ while chromosomal translocation AKAP9-BRAF occurs in radiation-related PTC (11\% vs. 1\%). ${ }^{20}$ Thus, these data revealed that MAPK pathway activation plays an important role in thyroid carcinogenesis, regardless of specific known driver mutations or rearrangements. Apart from that, radiation-induced PTC behave aggressively (extrathyroid and lymph node extensions) when compared to sporadic PTC. ${ }^{8}$ Indeed, radiation-related PTC expressed higher protein levels of matrix metalloproteinases (MMP-1, MMP-9, MMP13), often correlated to tumor aggressiveness. ${ }^{21}$

\section{ACUTE EFFECTS OF IONIZATION RADIATION ON THYROID CELLS}

In this review, acute effects are defined as the phenotype following hours or few days after single radiation dose exposure. Radiation responses vary according to tissue or cell type, dose and time. AbouEl-Ardat et al. (2012) ${ }^{22}$ reported that RET/PTCpositive thyroid cell line (TPC-1), derived from PTC, and normal thyroid cells distinctly respond to radiation. At low dose (62 mGy), X-ray enhanced normal thyroid cells proliferation and the opposite effect was observed in RET/PTC-positive cells. At high doses (0.5, 4 Gy), the latter activated P53 pathway while the former triggered TGF $\beta$. In accordance to that, TGF $\beta$ and SMAD (canonical TGF $\beta$ pathway) were also regulated in normal thyroid gland after ${ }^{131} \mathrm{I}$ administration in mice $^{23}$ and the profound diversity of biological responses to radiation doses were also recapitulated in vivo. So far, the main limitations of these models are: 1) the lack of temporal points; 2) most of the approaches have been conducted in immortalized cells; 3) Speciesspecific molecular alterations in response to radiation (i.e, RET/PTC only detected in humans). Accordingly, Mizuno et al. (1997) ${ }^{24}$ proposed a new model to investigate radiation effects that basically consists of 
human thyroid tissue engraftment into severe combined immunodeficiency (scid) mice. This model allowed subsequent studies to elucidate the properties and role of RET/PTC on thyroid carcinogenesis in humans. Gandhi and Nikiforov (2011) ${ }^{25}$ brought to life that rodents and humans do not share common nuclear architecture. The authors demonstrated that RET and fusion genes have spatial positioning differences between both species, which might explain the absence of human RET/PTC orthologs in rodents. Mizuno et al. (2000) ${ }^{26}$ also revealed that X-ray induces RET/PTC1 rather than RET/PTC3, in a time and dose-dependent manner.

\section{CHRONIC EFFECTS OF IONIZING RADIATION ON THYROID CELLS}

Herein, chronic effects are defined as the consequences of radiation exposure after a short or long period. First, chronic low $(\leq 100 \mathrm{mSv})$ and high doses $(>100 \mathrm{mSv})^{10}$ have different impacts on thyroid cells. Concerning low doses, linear-nonthreshold (LNT) model - assumes that cancer risk is linearly proportional to radiation dose - fails to predict risks for cancer incidence due to its fluctuations in low radiation doses, which limit statistical significance ${ }^{27,28}$. However, LNT optimization using Monte Carlo method - computational algorithm based on mathematical probability that calculates the organ and effective doses from interactions due to the Compton effect in the human body - indicated that, after cervical $\mathrm{X}$-ray, effective dose of thyroid is $1.48 \mathrm{mSv}$, and that, even minor doses potentially increase lifetime risk for developing thyroid cancer. ${ }^{29}$ Based on these findings, one aspect to consider is the worldwide increase in medical radiation exposure ${ }^{30}$ and the influence of these low-doses in radiosensitive organs as thyroid. Several studies successfully correlated number and radiation dose of CT Scans for infants and adolescents to a greater thyroid cancer risk, ${ }^{29,31,32}$ especially in females. Another relevant question is whether genetic alterations could predispose to radiation carcinogenic actions. Missense single nucleotide polymorphisms (SNP) of DNA damage response genes (ATM and TP53) were specifically associated to an increased thyroid cancer risk in sporadic and radiationrelated PTC. ${ }^{33}$ Moreover, post-Chernobyl PTC cases often carry a SNP in the DNA repair gene XRCC1 that potentially conferred a greater risk for thyroid cancer. ${ }^{34}$ Until now, literature is sparse about low-dose radiation. For example, acute exposure to $100 \mathrm{mSv}$ induces four DSB per cell while chronic exposure to $100 \mathrm{mSv}$ during the year promotes one DSB in one cell of 2400 cells per hour (Suzuki and Yamashita, 2012), so that further studies are necessary to understand its biological relevance.

Concerning chronic doses $>100 \mathrm{mSv}$, extensive data are available on literature. The vast majority of clinical and epidemiological studies are addressed above and most of them fitted LNT model to explain lifetime risk to thyroid cancer. A classic example of chronic radiation exposure is observed in population nearby Marshall islands that although nuclear test ceased in 1958, they were chronically affected by radiation due to fallout deposited on the ground until 1970, which reflected in one of the greatest female thyroid cancer rates in the world, 19.28 per 100,000 per year, age-

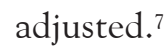

\section{SENESCENCE AND THYROID CELLS}

The concept that "cell division is not everlasting but finite" was originally proposed by the German August Weismann. ${ }^{35}$ After 80 years, Leonard Hayflick and Paul Moorhead (1961) ${ }^{36}$ revisited this concept and published the timeless work in which they fully characterized that normal human cell strains have finite replicative capacity and suggested that this phenomenon as ageing at cellular level or, more precisely, senescence. Later on, researchers established that normal human cells telomeres shorten as they reached Hayflick limit, ${ }^{37}$ replicative senescence, and it might determinate cell longevity. ${ }^{38}$

Senescent cells are mainly characterized by morphological and molecular features. ${ }^{39}$ During senescence, cells undergo multiple changes that distinguish them from quiescent or terminal differentiated cells: 1) morphology: flattened, elongated and enlarged cell shape; 2) metabolism: display high lysosomal $\beta$-D-galactosidase activity at $\mathrm{pH} 6$ due to increased numbers of lysosomes; 3) chromatin organization: irreversible RB-dependent heterochromatin structures, named as SenescenceAssociated Heterochromatin Foci (SAHF); 4) The senescence-associated secretory phenotype (SASP): proinflamatory cytokines, chemokines and extracellular matrix metalloproteinases; 5) cell cycle arrest in early G1 mediated by p53, p21 and p16.

The paradoxical behavior of senescent cells in tumorigenesis is still an enigma to be clarified. The concept of senescence providing a barrier to cell proliferation is well-accepted, although its contribution on different stages of carcinogenesis is yet to be elucidated. The key to understand this phenomenon rely on the crosstalk between the stromal and tumor cells, and how SASP might originate an altered microenvironment that promotes tumor progression. ${ }^{40}$ 
However, these questions remain unanswered for thyroid carcinoma.

Senescence itself is not necessarily induced by the physical presence of shortened telomeres or DSB in eroded telomeres, but rather as a result of the signaling pathways triggered in response to them. ${ }^{41}$ In fact, stress-inducible senescence, which encompasses oncogene activation and exogenous stimuli (i.e., ionizing radiation), often occurs in a telomere-independent manner. The first strong evidence came from Serrano et al. (1997) ${ }^{42}$ in which RAS activation promoted permanent arrest in early G1 mediated by p53 and p16, a senescence-like phenotype. Similar results were obtained in primary thyrocytes, in which the proinflamatory cytokine
IL-8 and its receptor CXCR2 support growth arrest triggered by oncogenic RAS, in agreement with the notion that senescence is intrinsically associated with inflammation. ${ }^{43}$ Recently, Cisowski et al. (2015) ${ }^{44}$ demonstrated that RAS and BRAF ${ }_{\mathrm{V} 600 \mathrm{E}}$ coactivation in early carcinogenesis induced senescence in lung cancer cells, leading to a negative clonal selection, which might be a plausible explanation for the reason why mutated RAS and $\mathrm{BRAF}_{\mathrm{V} 600 \mathrm{E}}$ are mutually exclusive in thyroid carcinoma.

Radiation plays a pleotropic role in cellular biological process. Several works proposed IR as a senescence inducer in human diploid cells through P53 activation without telomere shortening. ${ }^{45-47}$ In thyroid context, to our knowledge, one article

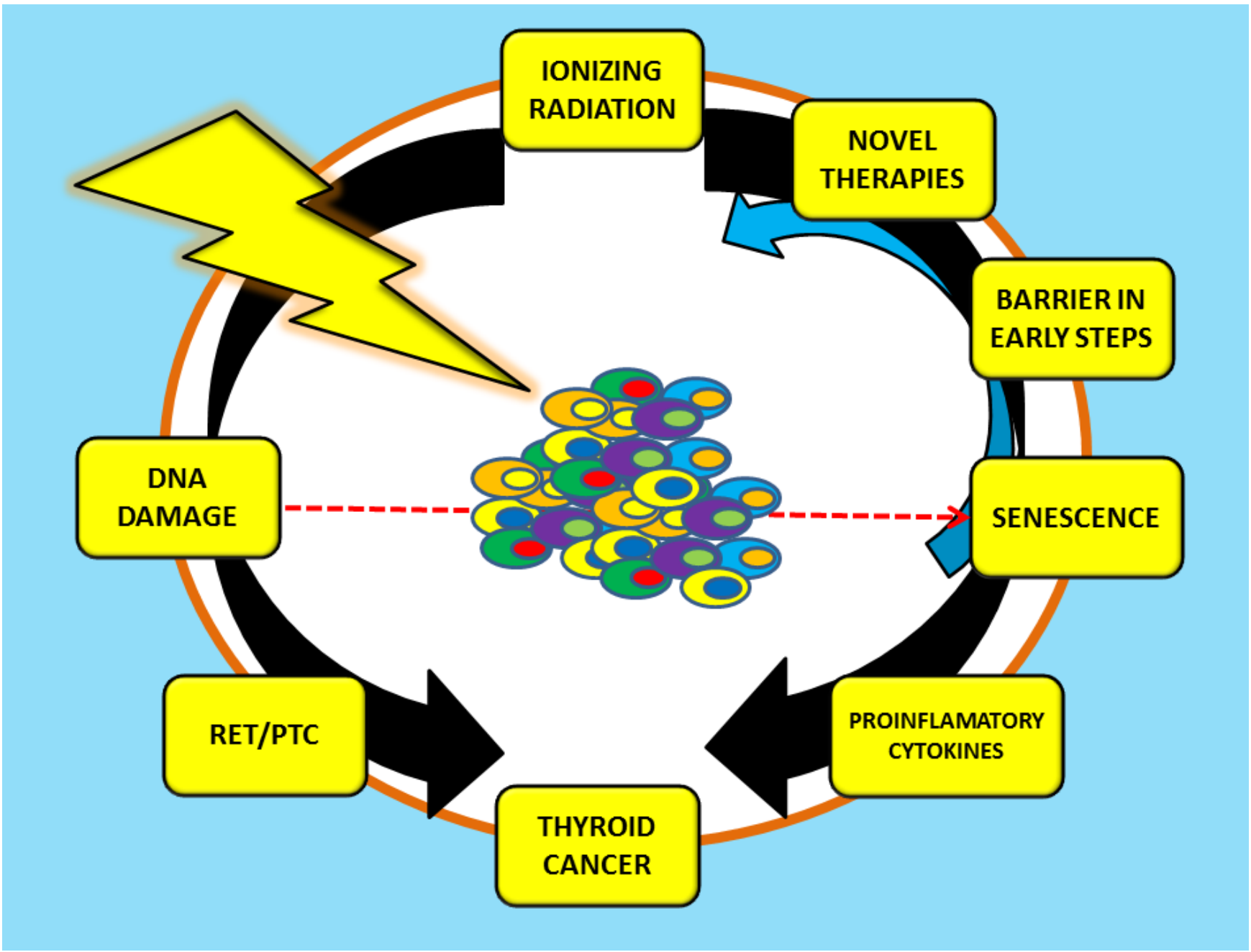

Figure 1. Schematic physical thyroid carcinogenesis overview. Ionizing radiation induces DNA damages, especially DNA doublestrand breaks, often correlated to RET/PTC generation. RET/PTC oncogenic activity leads normal follicular cells to acquire malignant phenotype (anticlockwise black arrow; pro-oncogenic pathway). Ionizing radiation could also induce premature senescence that represents a barrier to cancer cells in early steps of thyroid carcinogenesis (anticlockwise blue arrow; anti-oncogenic pathway) and/or promotes senescence-associated secretory phenotype and releasing of proinflamatory cytokines (i.e., IL-8), that contribute to cancer progression (clockwise black arrow; pro-oncogenic pathway). Rather than DNA damages, signaling pathways triggered in response to them induce senescence (dashed red line; crosstalk). 


\section{Proliferating FRTL5}

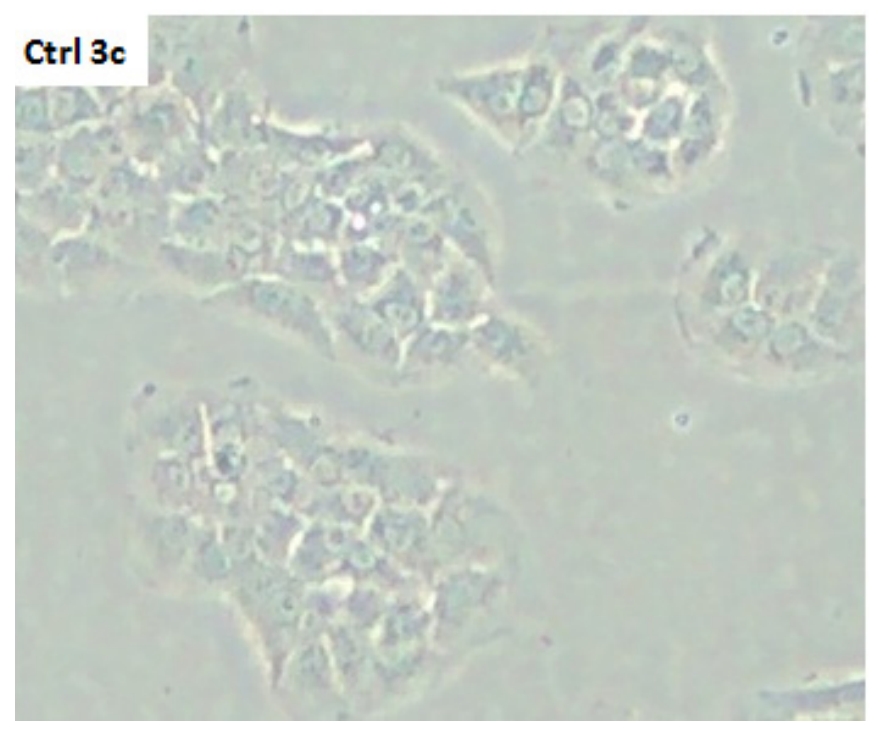

\section{Senescent FRTL5}

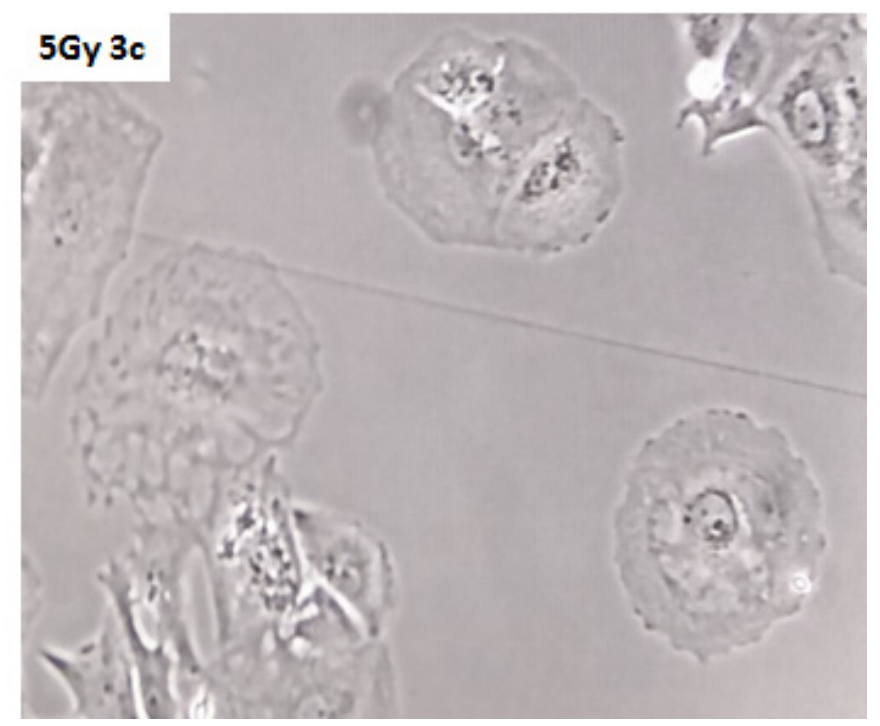

Figure 2. X-ray promotes senescence in normal thyroid cells (FRTL5). Normal rat thyroid cell line (FRTL5) was chronically exposed to X-ray, 3 cycles of $5 \mathrm{~Gy}$, with an accumulative radiation dose of 15 Gy and senescence morphology was observed in irradiated cells: flattened, elongated and enlarged cell shape. CTRL $3 \mathrm{c}=$ non-exposed cells; $5 \mathrm{~Gy} 3 \mathrm{c}=$ irradiated cells after an accumulative radiation dose $(15 \mathrm{~Gy})$.

reported that radiation induced premature senescence in synergism with thyroid hormone receptor beta, ${ }^{48}$ a suppressor gene proposed as a novel inducer of cellular senescence in thyroid cells. ${ }^{49}$ Thus, one of our research interests is to investigate the parallel between thyroid carcinogenesis and premature senescence related to ionizing radiation, focusing on the turning point in which radiation might lead a normal thyroid cell to gain proliferative advantages among surrounding cells in early thyroid carcinogenesis or senescence. To this end, the normal rat thyroid FRTL5 cell line were chronically exposed to X-ray, based on the mean radiation dose ( $25 \mathrm{~Gy}$ ) for childhood cancer treatment $^{6}$ and senescence morphology were observed after three cycles of 5 Gy (Figure 2) (unpublished data). Once the senescence model was established, the future steps consist of full molecular characterization of each time point in order to identify molecular alterations that might guide us to a better understanding of thyroid carcinogenesis.

\section{CONCLUSIONS}

DNA damage induced by ionizing radiation could lead normal thyroid cells to acquire a malignant phenotype, mediated by oncogenic activity of RET/ PTC-MAPK pathway. Dose and time of radiation exposure dictates different molecular responses and, as a matter of fact, only a full characterization of the molecular alterations will bring light to the genesis of thyroid cancer. LNT model fits high acute or chronic radiation doses to explain lifetime attributable risk for thyroid cancer while LNT model combined with Monte Carlo simulations predict low doses exposure. Pathways trigged by unrepaired DNA damage rather than damage itself activate senescence that act as a barrier to cancer progression. Taking into account the irreversible state of senescence, novel therapyinduced senescence is a promising approach that might induce a persistent growth inhibitory response in both early- and late steps of carcinogenesis while reducing toxicity, ${ }^{50}$ and thus, could be an alternative treatment to iodine-refractory thyroid tumors.

\section{ACKNOWLEDGMENTS}

The study was supported by P.O.R. Campania FSE 2007-2013, CUP B25B09000050007, PNR-CNR Aging "Program 2012-2014" and Grant IG-11477 from the Associazione Italiana Ricerca sul Cancro (AIRC - Italy). AF was granted with a Special Visiting Researcher (PVE) fellowship sponsored by CAPES. 


\section{REFERENCES}

1. DeLellis RA, Lloyd RV, Heitz PU. World Health Organization Classification of Tumours. Pathology and Genetics of Tumours of Endocrine Organs. IARC Press: Lyon (France); 2004.

2. Instituto Nacional do Câncer (INCA). Estimativa 2014 de Incidência de Câncer no Brasil. Rio de Janeiro (Brazil): INCA; 2014.

3. Albores-Saavedra J, Henson DE, Glazer E, et al. Changing patterns in the incidence and survival of thyroid cancer with follicular phenotype-papillary, follicular, and anaplastic: a morphological and epidemiological study. Endocr Pathol. 2007;18:1-7.

4. Kondo T, Ezzat S, Asa SL. Pathogenetic mechanisms in thyroid follicular-cell neoplasia. Nat Rev Cancer 2006;6: 292-306.

5. American Cancer Society. Cancer Facts \& Figures 2014. Atlanta (US): American Cancer Society; 2014.

6. Ron E, Lubin JH, Shore RE, et al. Thyroid Cancer after Exposure to External Radiation: A Pooled Analysis of Seven Studies. Radiat. Res. 1995;141:259-277.

7. Land CE, Bouville A, Apostoaei I, et al. Projected lifetime cancer risks from exposure to regional radioactive fallout in the Marshall Islands. Health Phys. 2010;99:201-15.

8. Pacini F, Vorontsova T, Demidchik EP, et al. Post-Chernobyl thyroid carcinoma in Belarus children and adolescents: comparison with naturally occurring thyroid carcinoma in Italy and France. J Clin Endocrinol Metab. 1997;82:3563-9.

9. Cardis E, Howe G, Ron E, et al. Cancer consequences of the Chernobyl accident: 20 years on. J Radiol Prot. 2006;26: $127-40$.

10. United Nations Scientific Committee on the Effects of Atomic Radiation (UNSCEAR). Sources and effects of ionizing radiation. New York (US): 2008 Report; Sales No. E.10.XI.3.

11. Ward, J. DNA damage as the cause of ionizing radiationinduced gene activation. Radiat. Res. 1994;138:S85-S88.

12. Sarasin A, Bounacer A, Lepage F, et al. Mechanisms of mutagenesis in mammalian cells. Application to human thyroid tumours. C R Acad Sci III. 1999;322:143-9.

13. Little JB. Radiation carcinogenesis. Carcinogenesis. 2000; 21:397-404.

14. Caudill CM, Zhu Z, Ciampi R, et al. Dose-dependent generation of RET/PTC in human thyroid cells after in vitro exposure to $\gamma$-radiation: a model of carcinogenic chromosomal rearrangement induced by ionizing radiation. J Clin Endocrinol Metab 2005;90:2364-9.

15. Port M, Boltze C, Wang Y, et al. A radiation-induced gene signature distinguishes post-Chernobyl from sporadic papillary thyroid cancers. Radiat Res. 2007;168: 639-49.

16. Bounacer A, Wicker R, Caillou B, et al. High prevalence of activating ret proto-oncogene rearrangements, in thyroid tumors from patients who had received external radiation. Oncogene 1997;15:1263-73.

17. Tronko M, Bogdanova T, Voskoboynyk L, et al. Radiation induced thyroid cancer: fundamental and applied aspects. Exp Oncol. 2010;32:200-204.

18. Fusco A, Grieco M, Santoro M, et al. A new oncogene in human thyroid papillary carcinomas and their lymph-nodal metastases. Nature. 1987;328:170-2.
19. Lima J, Trovisco V, Soares P, et al. BRAF mutations are not a major event in post-Chernobyl childhood thyroid carcinomas. J Clin Endocrinol Metab. 2004;89:4267-71.

20. Ciampi R, Knauf JA, Kerler R, et al. Oncogenic AKAP9. BRAF fusion is a novel mechanism of MAPK pathway activation in thyroid cancer. J Clin Invest. 2005;115: 94-101.

21. Boltze C, Riecke A, Ruf CG, et al. Sporadic and radiationassociated papillary thyroid cancers can be distinguished using routine immunohistochemistry. Oncol Rep. 2009;22:459-67.

22. Abou-El-Ardat K, Monsieurs P, Anastasov N, et al. Low dose irradiation of thyroid cells reveals a unique transcriptomic and epigenetic signature in RET/PTC-positive cells. Mutat Res. 2012;731:27-40.

23. Rudqvist N, Schüler E, Parris TZ, et al. Dose-specific transcriptional responses in thyroid tissue in mice after (131) I administration. Nucl Med Biol. 2015;42:263-8.

24. Mizuno T, Kyoizumi S, Suzuki T, et al. Continued expression of a tissue specific activated oncogene in the early steps of radiation-induced human thyroid carcinogenesis. Oncogene. 1997;15:1455-60.

25. Gandhi M, Nikiforov YE. Suitability of animal models for studying radiation-induced thyroid cancer in humans: evidence from nuclear architecture. Thyroid. 2011;21: 1331-7.

26. Mizuno T, Iwamoto KS, Kyoizumi S, et al. Preferential induction of RET/PTC1 rearrangement by X-ray irradiation. Oncogene. 2000;19:438-43.

27. Trosko JE, Chang CC, Upham BL, et al. Low-dose ionizing radiation: induction of differential intracellular signalling possibly affecting intercellular communication. adiat Environ Biophys. 2005;44:3-9.

28. Suzuki K, Yamashita S. Low-dose radiation exposure and carcinogenesis. Jpn J Clin Oncol. 2012;42:563-8.

29. Seo D, Han S, Kim KH, et al. Evaluation based on Monte Carlo simulation of lifetime attributable risk of cancer after neck X-ray radiography. Radiol Med. 2015; Epub ahead of print.

30. Schonfeld SJ, Lee C, Berrington de González A. Medical exposure to radiation and thyroid cancer. Clin Oncol (R Coll Radiol) 2011;23:244-50.

31. Su YP, Niu HW, Chen JB, et al. Radiation dose in the thyroid and the thyroid cancer risk attributable to CT scans for pediatric patients in one general hospital of China. Int J Environ Res Public Health. 2014;11:2793-803.

32. Boice JD Jr. Radiation epidemiology and recent paediatric computed tomography studies. Ann ICRP. 2015;44:236-48.

33. Akulevich NM, Saenko VA, Rogounovitch TI, et al. Polymorphisms of DNA damage response genes in radiationrelated and sporadic papillary thyroid carcinoma. Endocr Relat Cancer. 2009;16:491-503.

34. Shkarupa VM, Henyk-Berezovska SO, Neumerzhytska LV, et al. Allelic polymorphism of DNA repair gene XRCC1 in patients with thyroid cancer who were exposed to ionizing radiation as a result of the Chernobyl accident. Probl Radiac Med Radiobiol. 2014;19:377-388.

35. Weismann, A. Collected Essays upon Heredity and Kindred Biological Problems (ed. Poulton, E. B.) (Clarendon, Oxford, 1889).

36. Hayflick L, Moorhead PS. The serial cultivation of human diploid cell strains. Exp. Cell Res. 1961;25:585-621. 
37. Harley CB, Futcher AB, Greider CW. Telomeres shorten during ageing of human fibroblasts. Nature 1990;345: 458-60.

38. Hayflick, L. A brief overview of the discovery of cell mortality and immortality and of its influence on concepts about ageing and cancer. Pathol. Biol. 1999;47:1094-104.

39. Kuilman T, Michaloglou C, Mooi WJ, et al. The essence of senescence. Genes Dev. 2010;24:2463-79.

40. Coppé JP, Desprez PY, Krtolica A, et al. The senescenceassociated secretory phenotype: the dark side of tumor suppression. Annu Rev Pathol. 2010;5:99-118.

41. Klement K, Goodarzi AA. DNA double strand break responses and chromatin alterations within the aging cell. Exp Cell Res. 2014;329:42-52.

42. Serrano M, Lin AW, McCurrach ME, et al. Oncogenic ras provokes premature cell senescence associated with accumulation of p53 and p16INK4a. Cell. 1997;88:593602.

43. Vizioli MG, Possik PA, Tarantino E, et al. Evidence of oncogene-induced senescence in thyroid carcinogenesis. Endocr Relat Cancer. 2011;18:743-57.
44. Cisowski J, Sayin VI, Liu M, et al. Oncogene-induced senescence underlies the mutual exclusive nature of oncogenic KRAS and BRAF. Oncogene. 2015; Epub ahead of print.

45. Suzuki K, Mori I, Nakayama Y, et al. Radiation-induced senescence-like growth arrest requires TP53 function but not telomere shortening. Radiat Res. 2001;155:248-253.

46. Meng A, Wang Y, Van Zant G, et al. Ionizing radiation and busulfan induce premature senescence in murine bone marrow hematopoietic cells. Cancer Res. 2003;63:5414-9.

47. Mirzayans R, Andrais B, Scott A, et al. Ionizing radiationinduced responses in human cells with differing TP53 status. Int J Mol Sci. 2013;14:22409-35.

48. Matsuse M, Saenko V, Sedliarou I, et al. A novel role for thyroid hormone receptor beta in cellular radiosensitivity. J Radiat Res. 2008;49:17-27.

49. Zambrano A, García-Carpizo V, Gallardo ME, et al. The thyroid hormone receptor $\beta$ induces DNA damage and premature senescence. J Cell Biol. 2014;204:129-46.

50. Ewald JA, Desotelle JA, Wilding G, et al. Therapy-Induced Senescence in Cancer. Natl Cancer Inst. 2010;102:1536-46. 